\title{
Comparison of Crystallinity between Natural Hydroxyapatite and Synthetic cp-Ti /HA Coatings
}

\author{
Camila Molena de Assis, Luci Cristina de Oliveira Vercik*, Márcio Luís dos Santos, \\ Marcus Vinícius Lia Fook, Antonio Carlos Guastaldi \\ Grupo de Biomateriais, Instituto de Química, Unesp Araraquara \\ Av. Prof. Francisco Degni, s/n, Quitandinha, Araraquara - SP, Brazil
}

Received: November 23, 2003, Revised: February 16, 2005

\begin{abstract}
Commercial purity titanium (cp-Ti), and some of its alloys are important materials in the medical field because of their excellent biocompatibility and mechanical properties. Recently a simple chemical method to induce bioactivity in these inert metallic materials was reported. In this work, the biomimetic chemical process has been used to modify the surface of $\mathrm{cp}$-Ti with the formation of a deposit layer of apatite (a calcium phosphate compound). The main purpose was to study the influence of heat treatment on changes in crystallinity in the deposited phases. X-ray diffraction analysis and scanning electron microscopy showed that the apatite coatings heat treated between 400 and $600{ }^{\circ} \mathrm{C}$ were less crystalline, similar to biological apatites. Upon heat treatment at temperatures above $700{ }^{\circ} \mathrm{C}$, the apatite coatings appeared more crystalline, and were a mixture of hydroxyapatite, octacalcium phosphate and magnesium phosphate.
\end{abstract}

Keywords: biomaterials, titanium, biomimetic process, hydroxyapatite

\section{Introduction}

The diversity of applications of biomaterials, the different chemical composition and the need for appropriate morphological forms for its use, requires interdisciplinary research work that considers aspects such as: surface treatment, synthesis routes, processing techniques (in various forms), degradability as well as local and systemic biocompatibility. In a similar manner, the development of bioceramics and prosthesis also require interdisciplinary work ${ }^{1}$.

In this context, the different areas of research and development can contribute significantly to increase the number of applications of bioceramics, by developing novel and more efficient biomaterials, by elucidating mechanisms that govern bone regeneration and by determining physical and chemical characteristics of different metal surfaces on which in-vitro nucleation of calcium phosphate can be stimulated. Creation of a rough surface or a porous film on an implant can reduce the long periods required for interfacial bonding between implant and bone. It can also increase the surface area available for the juxtaposition bone-implant and enhance osseointegration ${ }^{2}$. This means that the normal remodeled bone is in contact with the implant surface with no interposition of connective tissue, but bone cells ${ }^{3}$.

Medicine and dentistry have studied calcium phosphate-based ceramics for over thirty years. Interest in a particular phase of calcium phosphates, the hydroxyapatite $(\mathrm{HA}), \mathrm{Ca}_{10}\left(\mathrm{PO}_{4}\right)_{6}(\mathrm{OH})_{2}$, appeared because of its great similarity with the main component present in the mineral phase of bones. The high bioactivity (strong ceramic/bone tissue interaction) and biocompatibility of HA increased its acceptance as an implant ${ }^{4}$. Coating of metallic implants, such as commercially pure titanium (cp-Ti) and its alloys with HA is one of its main applications. The basic idea is to combine the advantageous mechanical properties of the metals with the excellent biocompatibility and bioactivity of the HA.

Among the various methods used to obtain HA coatings, the physical techniques ${ }^{5-7}$, produce high quality coatings and high density films. The main disadvantages of these techniques are the use of so- phisticated and expensive equipment and reduced adhesion, because of a lack of chemical bonding, between the metal and the apatite coating. These are the main reasons for studying novel techniques, most of which are chemical methods ${ }^{4,8,9}$.

The biomimetic $c^{4,10,11}$ method is one of the most promising techniques for the production of biomaterials in body environment conditions. This method consists in immersing the substrate to be coated in a synthetic solution (SBF - Simulated body fluid), with chemical composition and $\mathrm{pH}$ similar to that of blood plasma and temperature similar to that of the human body. This technique permits complex forms, porous and temperature sensitive materials, such as polymers, to be coated. Further, the HA obtained using this method is similar to the biological one.

\section{Materials and Methods}

\subsection{Treatment of cp-Ti with $\mathrm{NaOH}$ solution}

The cp-Ti substrate was cut into small bars $0.5 \times 0.5 \times 0.3 \mathrm{~cm}$ and polished with a 150 mesh sandpaper. The substrates were washed in an ultrasonic cleaner with alcohol, acetone and deionized water for 10 minutes. Immediately afterwards, the substrates were etched in $5 \mathrm{M}$ $\mathrm{NaOH}$ solution for 24 hours at $60{ }^{\circ} \mathrm{C}$ and heat treated at $600{ }^{\circ} \mathrm{C}^{12}$.

\subsection{Apatite coating on $\mathrm{cp}-\mathrm{Ti}$}

After the treatment with $\mathrm{NaOH}$ solution, the substrates were immersed in a solution of sodium silicate for 24 hours at $37{ }^{\circ} \mathrm{C}$. Subsequently, the substrate was treated with a SBF solution, for slow and organized nucleation of apatite on the substrate to be coated. Immediately after, the substrates were immersed for six days at $37^{\circ} \mathrm{C}$ in a solution 1.5 SBF for the growth of apatite. Table 1 shows the ionic concentrations of the blood plasma and all the solutions used in this process. 


\subsection{Heat treatment of the apatite coating}

After coating the substrates, the samples were heat treated at $400,500,600,700$ and $800{ }^{\circ} \mathrm{C}$, without atmospheric control and at heating rate of $5{ }^{\circ} \mathrm{C} / \mathrm{min}$.

\subsection{Characterization of the apatite coating}

After the heat treatment, all the coatings were characterized using scanning electron microscopy (SEM), infrared spectroscopy (FTIR) and X-ray diffraction analysis (XRD).

\section{Results and Discussion}

Figure 1 shows the scanning electron micrographs of the cp-Ti surface after alkaline treatment. As a thin passive layer of titanium dioxide $\left(\mathrm{TiO}_{2}\right)$ forms spontaneously on the $\mathrm{cp}-\mathrm{Ti}^{13}$ substrate, it was treated with $5 \mathrm{M} \mathrm{NaOH}$ to produce a more favorable and active surface on the passive layer of $\mathrm{TiO}_{2}$, to induce the precipitation of apatite ${ }^{13-15}$.

During the alkaline treatment, the passive $\mathrm{TiO}_{2}$ surface can react in the following manner ${ }^{13,16}$ :

$$
\begin{aligned}
& \mathrm{TiO}_{2}+\mathrm{OH}^{-} \rightarrow \mathrm{HTiO}_{3}{ }^{-} \\
& \mathrm{Ti}+3 \mathrm{OH}^{-} \rightarrow \mathrm{Ti}(\mathrm{OH})_{3}^{+}+4 \mathrm{e}^{-}
\end{aligned}
$$
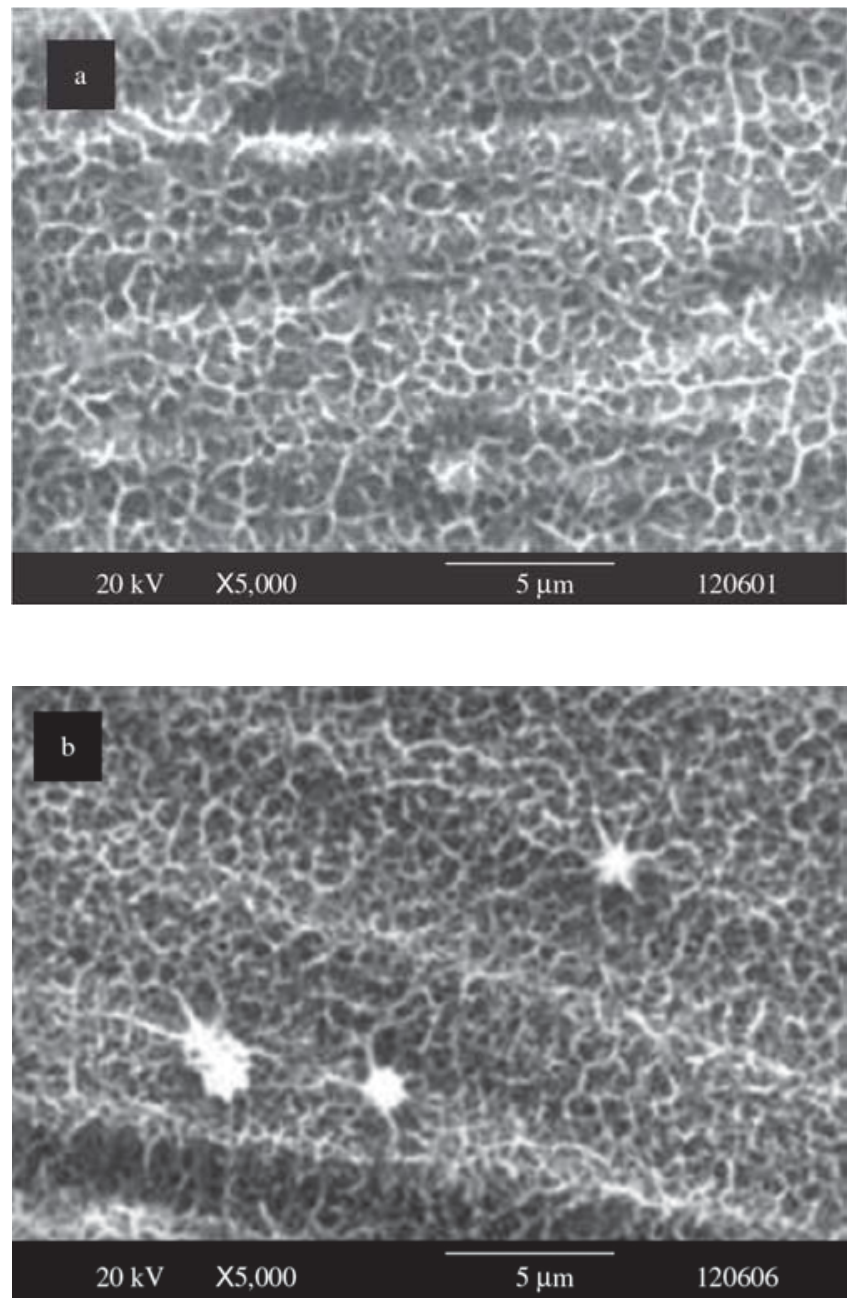

Figure 1. SEM micrographs of the surface of cp- Ti metal: a) $5-\mathrm{M} \mathrm{NaOH}$ treated; b) after subsequent heat treatment at $600{ }^{\circ} \mathrm{C}$.

$$
\begin{aligned}
& \mathrm{Ti}(\mathrm{OH})_{3}^{+}+\mathrm{e}^{-} \rightarrow \mathrm{TiO}_{2} \mathrm{H}_{2} \mathrm{O}+1 / 2 \mathrm{H}_{2}(\mathrm{~g}) \\
& \mathrm{Ti}(\mathrm{OH})_{3}^{+}+\mathrm{OH}^{-} \Leftrightarrow \mathrm{Ti}(\mathrm{OH})_{4} \\
& \mathrm{TiO}_{2} n \mathrm{H}_{2} \mathrm{O}+\mathrm{OH}^{-} \Leftrightarrow \mathrm{HTiO}_{3}^{-} n \mathrm{H}_{2} \mathrm{O}
\end{aligned}
$$

The negatively charged species combine with the alkaline ions in the aqueous solution, to form an alkaline layer of titanate hydrogel. During the heat treatment, this hydrogel layer is dehydrated and stabilized as a crystalline sodium titanate layer ${ }^{13,16}$, Figure 2.

The formation of insufficient Ti-OH groups, as a consequence of the amphoteric nature of $\mathrm{TiO}_{2}$, inhibits the formation of enough nuclei on the cp-Ti to produce a dense and uniform layer of apatite. Therefore, the immersion of these substrates in a solution of a salt which has a tendency to increase the $-\mathrm{OH}$ bridges and not displace the equilibrium of the media, will increase the active sites on the cp-Ti surface ${ }^{17,18}$. In this investigation a solution of sodium silicate was used to increase apatite nucleation, through the formation of $\mathrm{Si}-\mathrm{OH}$ groups, which is accelerated when immersed in a SBF solution for 24 hours (Table 1). When the substrates were immersed in a SBF solution that is 1.5 times more concentrated than the original one, (Table 1) the apatite nuclei grew spontaneously by consumption of calcium and phosphate ions of the solution, to form a uniform apatite layer.

The composition of the apatite coating on the hydrogel surface was determined by XRD (Figure 3). It can be observed that for heat treatments at 400,500 and $600{ }^{\circ} \mathrm{C}$, the X-ray difractograms of the coatings exhibit three wide bands at approximately $2 \theta=26^{\circ}$, $2 \theta=29^{\circ}$ and $2 \theta=32^{\circ}$. These bands are characteristic of the large

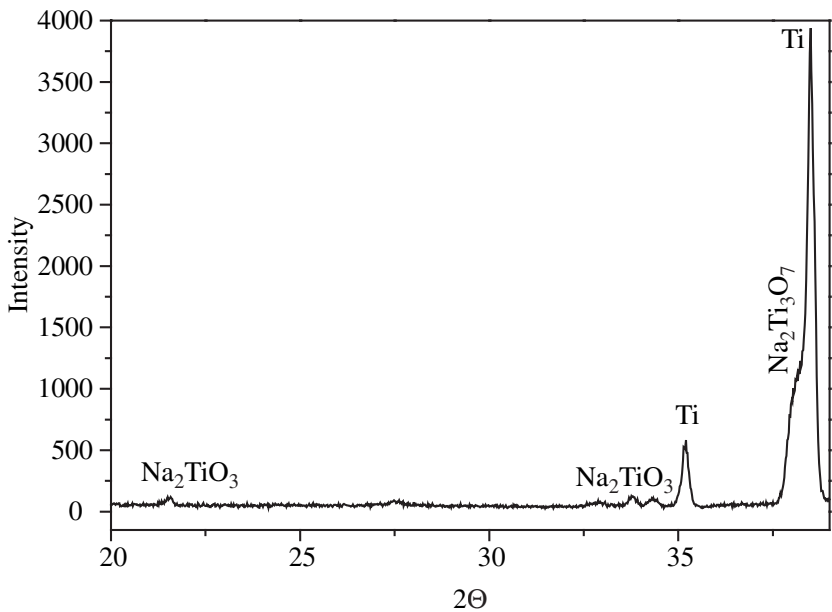

Figure 2. XDR pattern of sodium titanate on cp-Ti after treatment with $\mathrm{NaOH}$ and heat treatment at $600{ }^{\circ} \mathrm{C}$.

Table 1. Ionic concentrations of the solutions used for the apatite coating $\left(\mathrm{mmol} \cdot \mathrm{dm}^{-3}\right)$.

\begin{tabular}{lccccccccc}
\hline & $\mathrm{Na}^{+}$ & $\mathrm{K}^{+}$ & $\mathrm{Ca}^{2+}$ & $\mathrm{Mg}^{2+}$ & $\mathrm{HCO}_{3}^{2-}$ & $\mathrm{Cl}^{-}$ & $\mathrm{HPO}_{4}^{2-}$ & $\mathrm{SO}_{4}^{2-}$ & $\mathrm{SiO}_{3}^{2-}$ \\
\hline $\begin{array}{l}\text { Blood } \\
\text { Plasma }\end{array}$ & 142.0 & 5.0 & 2.5 & 1.5 & 27.0 & 103.0 & 1.0 & 0.5 & - \\
$\mathrm{SBF}$ & 142.0 & 5.0 & 2.5 & 1.5 & 4.2 & 148.0 & 1.0 & 0.5 & - \\
$1.5 \mathrm{SBF}$ & 213.0 & 7.5 & 3.8 & 2.3 & 6.3 & 223.0 & 1.5 & 0.75 & - \\
$\mathrm{Na}_{2} \mathrm{SiO}_{3}$ & 2.0 & - & - & - & - & 1.0 & - & - & 3.6 \\
\hline
\end{tabular}


number of peaks associated with apatite phases, indicating the presence of phases with low crystallinity, similar to that of biological apatite. The well defined peaks at $2 \theta=27.5^{\circ}$ and $2 \theta=36^{\circ}$ are due to the Ti substrate.

The low crystallinity of the phases in the coating leads to instabilities when implanted. According to literature ${ }^{3,16}$, amorphous calcium phosphates and mostly, the tetracalcium phosphate and tricalcicium phosphate phases are more soluble than HA, leading to rapid disintegration of the coating and loss of fixation of the implant, known as reabsorption.

Figure $3 \mathrm{~d}-3 \mathrm{e}$ shows the increase in crystallinity of the apatite coating with heat treatment at 700 and $800{ }^{\circ} \mathrm{C}$. It is possible to identify different types of apatites that precipitated on the $\mathrm{cp}-\mathrm{Ti}$ substrate. Besides the crystalline HA phase, some peaks of octocalcium phosphate (OCP), $\mathrm{Ca}_{8} \mathrm{H}_{2}\left(\mathrm{PO}_{4}\right)_{6} .5 \mathrm{H}_{2} \mathrm{O}$ and hydrated magnesium phosphate, $\mathrm{Mg}_{3}\left(\mathrm{PO}_{4}\right)_{2} \cdot \mathrm{H}_{2} \mathrm{O}$, were observed.

The OCP phase is considered to be the important one as it participates in bone formation and also because it is a precursor of the HA phase. According to Feng ${ }^{14}$, to obtain calcium phosphate coatings on Ti surfaces, the solution must be above the equilibrium value for OCP saturation. Once the OCP growth velocity exceeds its hydrolysis value, it is possible to form a mixture of OCP and HA phases ${ }^{19}$.

By varying the heat treatment temperature, it was possible to obtain a HA with crystalline structure similar to that of biological HA, as shown in Figure 4. This reveals the high efficiency of the biomimetic method and the influence of heat treatment on the coatings obtained by this method.

The scanning electron micrographs of the apatite coatings on cp-Ti show a deposit with uniform morphology, composed of spherical particles with size in the range 3-5 $\mu \mathrm{m}$, and some agglomerates formed by fusion of some particles during the heat treatments. It can be observed that with increase in heat treatment temperature, the morphology of the coatings are similar and free of cracks. After heat treatments at 700 and $800{ }^{\circ} \mathrm{C}$, a new phase, characterized as $\mathrm{Mg}_{3}\left(\mathrm{PO}_{4}\right)_{2} \cdot \mathrm{H}_{2} \mathrm{O}$ appeared, and this was also detected by XRD. The EDS analysis confirmed the appearance of magnesium as shown in Figure 5.

The crystallinity of the HA coating on cp-Ti surfaces and the phases of the phosphate precipitates during immersion were analyzed by infra-red (IR) spectroscopy.

Figure $6 \mathrm{a}, 6 \mathrm{~b}$ shows strong bands attributable to stretching and deformation of the $\mathrm{O}-\mathrm{H}$ group of water, and can be observed at 3300 and $1660 \mathrm{~cm}^{-1}$, respectively. Three bands related to the $\mathrm{CO}_{3}^{-2}$ group at $1457,1417 \mathrm{e} 877 \mathrm{~cm}^{-1}$, characterizing a carbonated hydroxyapatite were also observed. Because of the appearance of these bands it can be concluded that the $\mathrm{PO}_{4}^{-3}$ ions are substituted by the carbonate ions in the HA structure according to $\mathrm{Ca}_{8,3} \square_{1,7}\left(\mathrm{PO}_{4}\right)_{4,3}\left(\mathrm{CO}_{3}\right)_{3,7}\left(\mathrm{HPO}_{4}\right)_{0,7}(\mathrm{OH})_{0,3} \square_{1,7}$, where $\square$ means a vacancy. The band at $1100 \mathrm{~cm}^{-1}$ is attributed to P-O stretching, whereas the bands at 560 e $473 \mathrm{~cm}^{-1}$ are associated to deformation vibration of the $\mathrm{P}-\mathrm{O}$ in the $\mathrm{PO}_{4}$ group. This indicates that the phosphate ions have an ideal tetrahedral structure.

Figure $6 \mathrm{c}-6 \mathrm{e}$ show the spectra of the HA coating on cp-Ti after heat treatment at 600,700 and $800{ }^{\circ} \mathrm{C}$. Absence of the band associated to the stretching mode of the $\mathrm{O}-\mathrm{H}$ group of water is worth noting. The crystalline hydroxyapatite has two bands, at 3570 and $630 \mathrm{~cm}^{-1}$, as observed in the figure. The $\mathrm{P}-\mathrm{OH}$ bands, characteristic of the $\mathrm{HPO}_{4}{ }^{2-}$ group, were observed at 960 and $870 \mathrm{~cm}^{-1}$, confirming the presence of the octacalcium phosphate.

\section{Conclusions}

A coating with a uniform, homogeneous and porous apatite layer was obtained using a slow nucleation process. The major phase was apatite with small quantities of other phases, and the octacalcium phosphate phase was the HA precursor. Upon heat treatment at temperatures between 400 and $600{ }^{\circ} \mathrm{C}$, the phases exhibited low crystallinity, and this increased at temperatures above $700{ }^{\circ} \mathrm{C}$. To heat treat the coatings, $600^{\circ} \mathrm{C}$ was considered the ideal temperature to efficiently attain the HA phase with low crystallinity, similar to that of biological HA.

\section{Acknowledgments}

The authors wish to thank FAPESP (processes 00/11125-9) and CNPq/PIBIC.

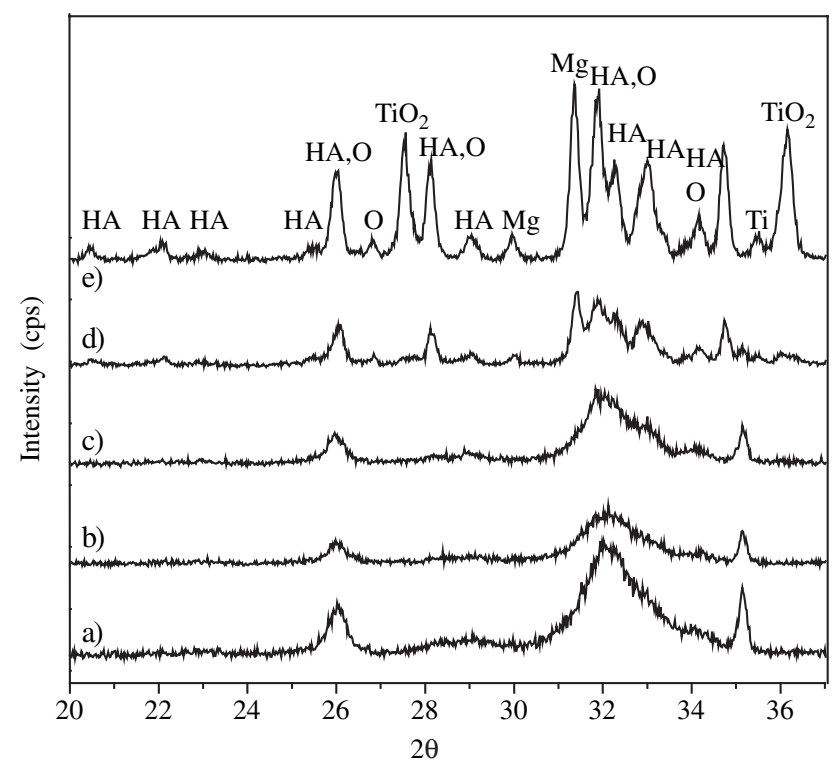

Figure 3. XDR pattern of phosphate coating on $\mathrm{cp}$-Ti after heat treatment: a) 400 ; b) 500 ; c) 600 ; d) 700 ; and e) $800^{\circ} \mathrm{C}$.

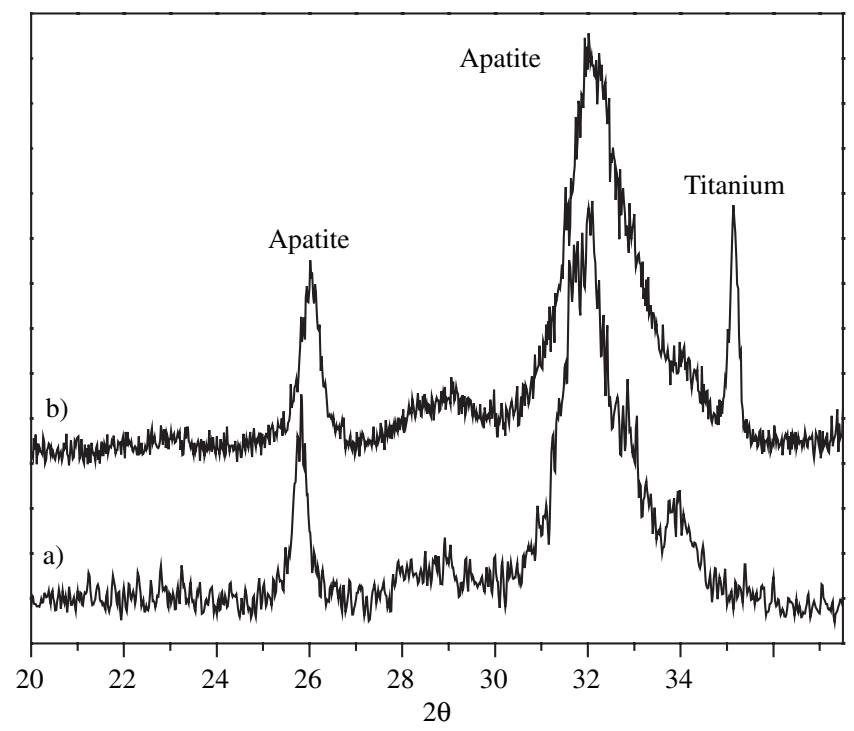

Figure 4. XDR pattern of: a) Biological jaw bone; b) HA coating heat treated at $600{ }^{\circ} \mathrm{C}$. 


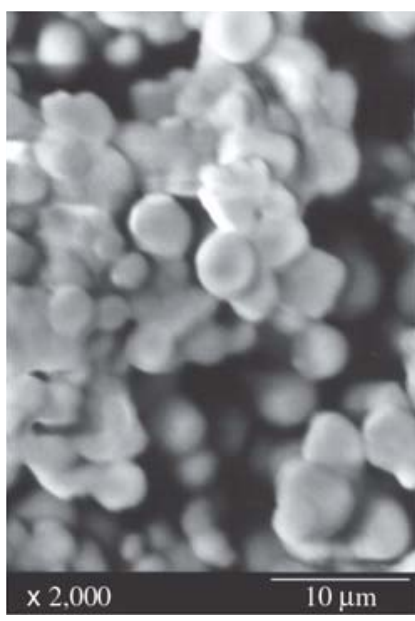

(a)

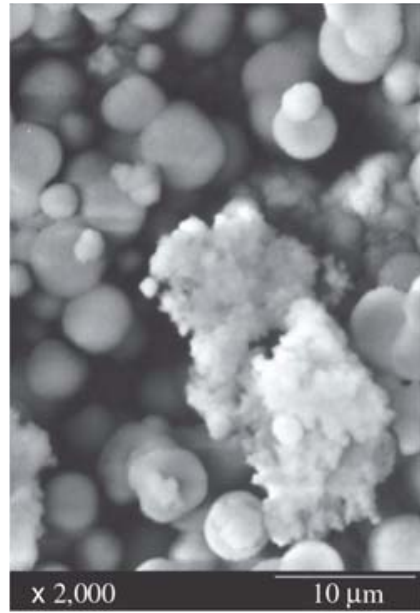

(e)

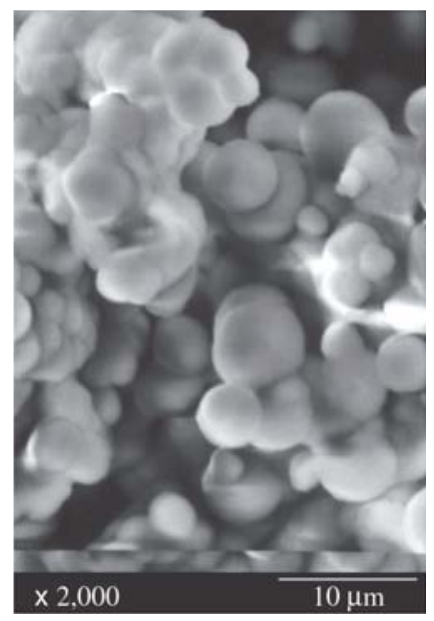

(b)

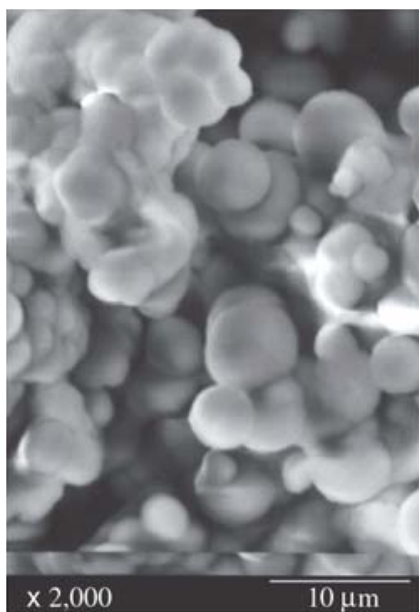

(c)

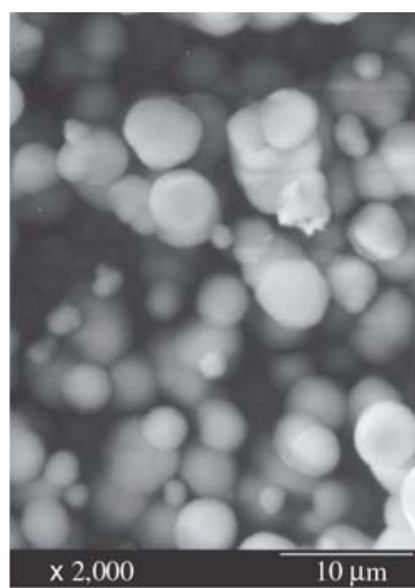

(d)

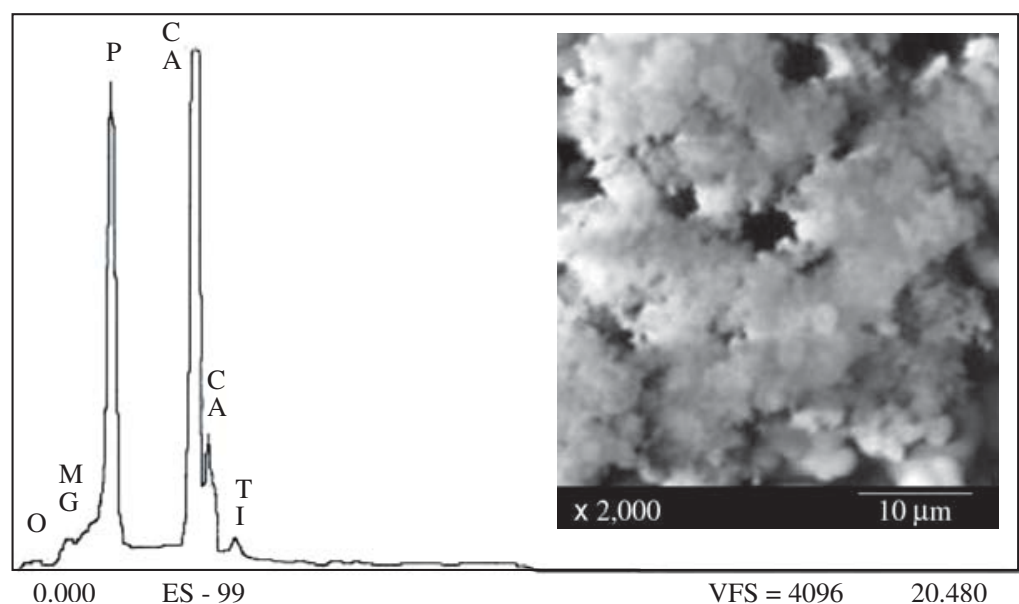

(f)

Figure 5. SEM micrographs of phosphate coatings on cp-Ti after a) 400; b) 500; c) 600; d) 700; and e) $800{ }^{\circ} \mathrm{C}$. (f) Morphology and EDX analysis of phosphate precipitate.

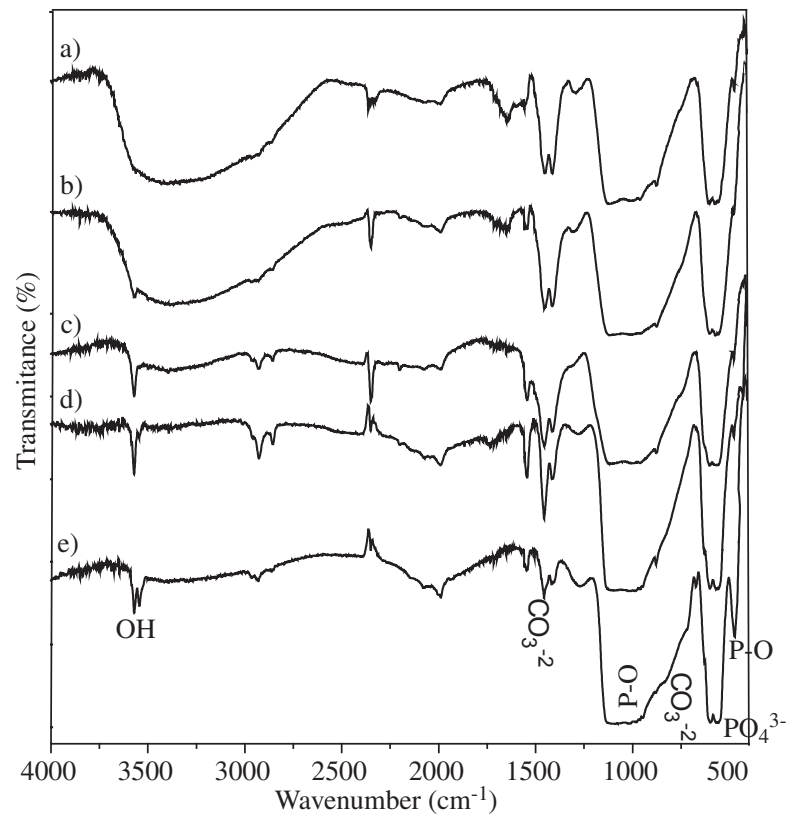

Figure 6. FTIR transmission spectra of phosphate coating on cp-Ti after heat treatment at: a) 400 ; b) 500 ; c) 600 ; d) 700 ; and e) $800^{\circ} \mathrm{C}$.

\section{References}

1. Kawachi EY, Bertran CA, Dos Reis RR, Alves OL. Bioceramics: tendencies and perspectives of na interdisciplinary área. Química Nova. 2000; 23(4):518-522.

2. Browne M, Gregson PJ. Effect of mechanical surface pretreatment on metal ion release. Biomaterials. 2000; 21(4):385-392.

3. Gross KA, Berndt CC, Goldschlag DD, Iacono VJ. In vitro changes of hydroxyapatite coatings. International Journal of Oral \& Maxillofacial Implants. 1997; 12(5):589-597.

4. Abe Y, Kokubo T, Yamamuro T. Apatite coating on ceramics, metals and polymers utilizing a biological process. Journal Materials. Science: Materials in Medicine. 1990; 1(4):233-238.

5. Nie X, Leyland A, Matthews A. Deposition of layered bioceramic hydroxyapatite $/ \mathrm{TiO}_{2}$ coatings on titanium alloys using a hybrid technique of micro-arc oxidation and electrophoresis. Surface \& Coating Technology. 2000; 125(1-3):407-414.

6. Park E, Condrate R A. Graded coating of hydroxyapatite and titanium by atmospheric plasma spraying. Materials Letter. 1999; 40(5):228-234.

7. Zeng HT, Lacefield WR. XPS, EDX and FTIR analysis of pulsed laser deposited calcium phosphate bioceramic coatings: the effects of various process parameters. Biomaterials. 2000; 21(1):23-30.

8. Monma H. Electrochemical deposition of calcium-deficient apatite on stainless-steel substrate. Journal of the Ceramic Society of Japan. 1993; 101(7):737-739 
9. Rigo ECS, Oliveira LC, Santos LA, Carrodéguas RG, Boschi AO. Implantes metálicos recobertos com hidroxiapatita. Revista Brasileira de Engenharia Biomédica. 1999; 15(1-2):21-29.

10. Barrere F, Layrolle P, Van Blitterswijk CA, De Groot K. Biomimetic calcium phosphate coatings on Ti6Al4V. A crystal growth study of octacalcium phosphate and inhibition by $\mathrm{Mg}^{2+}$ and $\mathrm{HCO}_{3}^{-}$. Bone. 1999; 25(2): 107s-111s

11. Martinez-Pérez CA, Martinez-Villafane A, Romero-Garcia J. Formación de hidroxiapatita sobre un superficie polimérica por um método biomimético. Revista Mexicana de Ingeniería Biomédica. 2000; 21(4):137141

12. Vercik LCO, Alencar AC, Ramirez I, Guastaldi AC. Dental implants: surface modification of cp-Ti using plasma-spraying and the deposition of hydroxyapatite. Materials Science Forum. 2003; 416(4):669-674.

13. Kokubo T. Apatite formation on surfaces of ceramics, metals and polymers in body environment. Acta Materialia. 1998; 46(7):2519-2527.

14. Feng QL, Cui FZ, WangH, Kim TN, Kim JO. Influence of solution condi- tions on deposition of calcium phosphate on titanium by $\mathrm{NaOH}$-treatment. Journal of Crystal Growth. 2000; 210 (4):735-740.

15. Wen HB, De Wijn JR, Liu Q, De Groot K. Preparation of bioactive microporous titanium surface by a new two-step chemical treatment. Journal Materials Science: Materials in Medicine. 1998; 9(3):121-128.

16. Gil FJ, Padrós A, Manero JM, Aparício C, Nilsson M, Planell JA. Growth of bioactive surfaces on titanium and its alloys for orthopaedic and dental implants. Materials Science Engineering C-Biomimetic and Supramolecular Systems. 2002; 22(1):53-60.

17. Miyaji F, Kim HM, Handa S, Kokubo T, Nakamura T. Bonelike apatite coating on organic polymers: novel nucleation process using sodium silicate solution. Biomaterials. 1999; 20(10):913-919.

18. Rigo ECS. Recobrimento biomimético de implantes metálicos com hidroxiapatita. [Tese Doutorado]. São Carlos: Universidade Federal de São de Carlos; 2001.

19. Shi JM, Ding CX, Wu YH. Biomimetic apatite layers on plasma-sprayed titanium coatings after surface modification. Surface \& Coating Technology. $2001 ; 137(1): 97-103$. 